\title{
Pre-Pleistocene Glaciation on Earth: Implications for Climatic History of Mars ${ }^{1}$
}

\author{
NICHOLAS CHRISTIE-BLICK \\ Exxon Production Research Company, P. O. Box 2189, Houston, Texas 77001
}

Received August 18, 1981; revised March 29, 1982

\begin{abstract}
The history of ice ages on Earth, extending back more than $2 \mathrm{Ga}\left(10^{9}\right.$ years), has been established by the recognition in strata of many ages of the assemblage of erosional features and deposits generated by glacial activity. The most useful indicators are widespread diamictite, striated and faceted clasts, polished and striated pavements, and laminites containing "dropstones" inferred to be ice-rafted.

The chronology of ancient glaciation is limited by our ability to recognize the results of glacial activity in an incomplete geologic record and by the age resolution attainable with available dating methods. Ice ages are currently known from the Early Proterozoic $(2.5-2.1 \mathrm{Ga}$ ago), several intervals in the Middle to Late Proterozoic (1.0-0.57 Ga), the Late Ordovician to Late Silurian (440-415 Ma, or $10^{6}$ years), possibly latest Devonian (360-345 Ma), Permo-Carboniferous (335$245 \mathrm{Ma}$ ), and late Cenozoic (26 Ma ago to the present). However, the timing of pre-Phanerozoic ice ages, occurring before $0.57 \mathrm{Ga}$ ago, is known only approximately, and glacial events would have been shorter than is suggested by the bracketing ages. A generally warm climate seems to have prevailed for the remainder of Earth history, although Mesozoic-Cenozoic seismic stratigraphic evidence suggests that a small ice sheet may have been a persistent feature near the south pole throughout the last $500 \mathrm{Ma}$.

Terrestrial climatic fluctuations occur on several time scales. The occurrence of ice ages on a time scale of $10^{8}-10^{9}$ years, and possibly higher-frequency fluctuations $\left(10^{6}-10^{7}\right.$ years), appears to be controlled by changes in solar output and atmospheric composition, and by the rearrangement of continents and oceans as a result of the motion of lithospheric plates. Climatic changes on a time scale of $10^{4}-10^{5}$ years are driven by perturbations of the Earth's orbital parameters. The principal evidence suggesting that significant climate changes have occurred on Mars consists of widespread dry channels (3.5-0.5 Ga?) and of geologically young dust-ice layered terrains in the polar regions ( $<10 \mathrm{Ma}$ ?). By analogy with the Earth, polar layered terrains have probably existed episodically on Mars for a considerable time although there is little direct evidence for this. Factors affecting a potential sedimentary record are the degree to which ice sublimed or melted, the effectiveness of eolian destruction of layering, and, in contrast to the present polar terrains, the tendency for ice to flow and slide over its substrate. As on Earth, climate changes on Mars have probably been induced by the long-term evolution of the atmosphere, by changes in solar luminosity, and by variations in orbital parameters. Major tectonic events may have affected Martian climate through changes in planetary obliquity.
\end{abstract}

\section{INTRODUCTION}

The history of ice ages on Earth extends back more than $2 \mathrm{Ga}^{2}$ (Fig. 1), and has been established by over a century of geologic

\footnotetext{
1 Presented at the "Workshop on Quasi-Periodic Climatic Changes on Earth and Mars" held at NASA's Ames Research Center, Moffett Field, California, February 24-26, 1981.

${ }^{2} 1 \mathrm{Ga}=10^{9}$ years. $1 \mathrm{Ma}=10^{6}$ years. $1 \mathrm{Ka}=10^{3}$ years.
}

investigation. Recent summaries are by Crowell and Frakes (1970), Steiner and Grillmair (1973), Keller (1973), Harland and Herod (1975), Crowell (1975, 1978), Edwards (1978), Frakes (1979), Pollack (1979), Harland (1981a), and Hambrey and Harland (1981), whose compilation is the most comprehensive currently available. Evidence for climate changes on Mars has been recognized comparatively recently following the observation of dry channels 


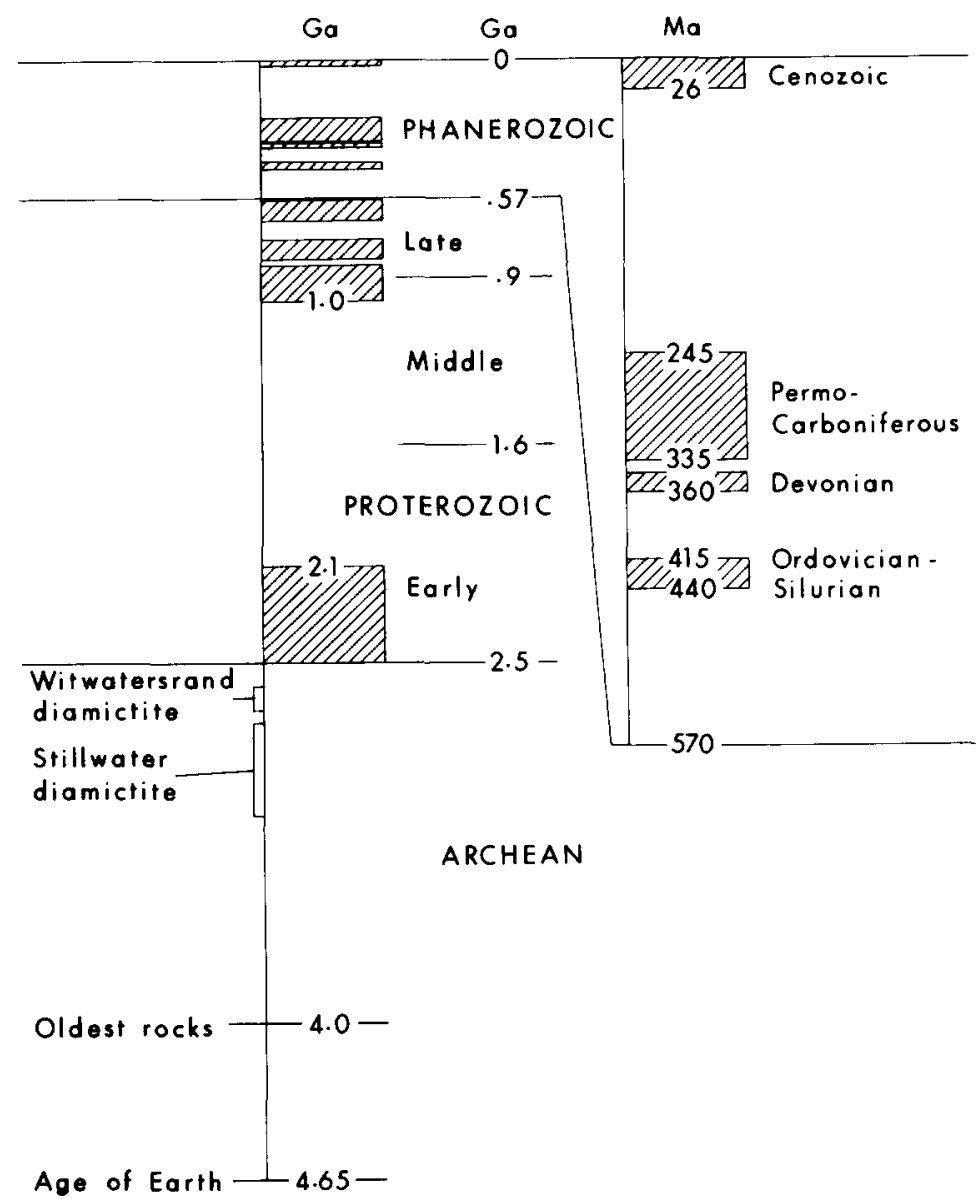

FIG. 1. Timing of ice ages on Earth (diagonal ruling). Ice ages indicated may include significant intervals of globally warm climate. Small ice sheets may have existed at times not normally considered as ice ages. The timing of Proterozoic glaciation is not well established.

and polar layered deposits by the Mariner 9 and Viking spacecraft (Pollack, 1979). It is therefore reasonable to ask whether any of the terrestrial experience bears on the investigation of Martian climate, and especially to consider the significance of periodic and episodic fluctuations in the climate of Earth in view of the rhythmic appearance of Martian layered deposits.

The purpose of this paper is threefold: (1) to present a brief overview of the history of pre-Pleistocene glaciation, emphasizing the uncertainties inherent in the recognition and dating of ice ages in an incomplete geologic record; (2) to review the evidence for and significance of periodic and episodic climatic fluctuations on Earth; and (3) to consider ways in which the terrestrial record may bear on the ancient climatic history of Mars. Details of relatively recent climatic fluctuations on both planets $\left(10^{4}\right.$ $10^{7}$ years) are discussed elsewhere in this volume.

\section{RECOGNITION OF ANCIENT GLACIATION ON EARTH}

A notable feature of terrestrial ice sheets and glaciers (in contrast to Martian ice caps) is their tendency to flow plastically and, where basal temperatures are at the 
melting point, to slide over their beds [summarized by Boulton (1975)]. Debris is incorporated in the moving ice by basal erosion and following the gravitational emplacement onto the ice of mass-wasted material from nunataks or valley sides. Subsequently, this debris is deposited directly from the ice, after gravitational flow or after partial sorting by water or wind (Boulton, 1972, 1975; Anderson et al., 1981). The principal way of recognizing ancient glaciation on Earth is therefore to identify the assemblage of erosional features and deposits generated by glacial activity.

An important product of glaciation is diamicton [or diamictite, where lithified; Flint et al (1960a,b)], a poorly sorted sediment in which clasts may range in size from boulders to clay-size material. Such diamicton (diamictite) is generally termed till (tillite) where a glacial origin is well established [see Boulton $(1976,1980)$ for a recent summary of terminology]. One difficulty is that not all diamictite is glaciogenic, and superficially similar rocks may on close scrutiny contain no definite glacial imprint (e.g., Crowell, 1957, 1964; Dott, 1961; Schermerhorn, 1974).

Criteria for establishing the occurrence of glaciation have been discussed by Crowell (1964), Schwarzbach (1964), Harland et al. (1966), Spencer (1971), Schermerhorn (1974), and Flint (1975). Without reviewing all the arguments, the most useful of many indicators are: (1) the occurrence of diamictite over a large area; (2) the presence in diamictite or associated conglomerate of hard, (glacially) striated and faceted clasts, some of which are far-traveled; (3) the occurrence beneath diamictite of a (glacially) polished and striated pavement; and (4) in subaqueous deposits, (ice-rafted) "dropstones" in finely laminated fine-grained rock matrix.

\section{DATING ANCIENT GLACIAL EVENTS ON EARTH}

The dating of glacial events on Earth is crucial to the elucidation of the causes of ice ages and especially in determining whether terrestrial glaciation has occurred periodically, episodically, or more or less continuously during some intervals. However, the chronology of ancient glaciation (Fig. 1) is limited by our ability to recognize the results of glacial activity in an incomplete geologic record and by the age resolution attainable with available dating methods.

Continental ice tends to be concentrated at high latitude, and even during a major ice age, glacial debris is usually distributed over only a small part of the Earth's continental shelves and interiors. During the Pleistocene, for example, the Scandinavian ice sheet spread southward nearly to latitude $51^{\circ} \mathrm{N}$ (Andersen, 1981) and the Laurentide sheet reached latitude $40^{\circ} \mathrm{N}$ (Mayewski et al., 1981), but only about $29 \%$ of the world's land area, including Antarctica, was covered by ice (Flint, 1971). This is in spite of the fact that land is currently concentrated at mid to high northern latitudes and near the south pole (Barron et al., 1981, Table 2). About $48.3 \%$ of the Earth's land occurs between latitudes 35 and $90^{\circ}(37.5 \%$ in the northern hemisphere and $10.8 \%$ in the southern hemisphere), whereas the total area between these latitudes constitutes only $42.6 \%$ of the surface of the globe. It is clear that if ice sheets have formed preferentially at high latitude for most or all of Earth history, the continental glacial record should be sparse even if the Earth were glaciated continuously.

In addition to limitations in the glacial record imposed by this latitude factor, earlydeposited till is removed or modified by the advancing ice sheet, and the final complex assemblage of till, outwash, and lacustrine sediment is subject to postglacial erosion. Glaciogenic sediment tends to accumulate unevenly, depending on factors such as subglacial topography and the temperature, velocity, and thickness of the ice (Boulton et al., 1977). If preserved in the interior of a continent, numerous unconformities are present, and it may be possible to decipher only the youngest history in any detail (e.g., 
the Pleistocene tills of North America and northern Europe). Where deposited on cratonic continental crust, glacial sections are typically only a few tens to hundreds of meters thick (Flint, 1971; Crowell and Frakes, 1970). Tillites of continental interiors are therefore more likely to be eroded than temporally equivalent thick sections in adjacent subsiding marine basins (Carey and Ahmad, 1961). For example, mostly marine basinal glaciogenic rocks of Late Proterozoic age occur at many localities in western North America (Crittenden et al., 1972; Christie-Blick et al., 1980), but equivalent platform rocks, themselves in part marine, are known only from northwestern Utah, where they overlie glacially sculptured topography (Crittenden et al., 1952; Blick, 1979; Ojakangas and Matsch, 1980). Elsewhere on this continental platform any record of glaciation has been eroded at a regionally extensive sub-Cambrian unconformity. There are of course some excellent examples elsewhere of well-preserved, nonmarine deposits, particularly in the $\mathrm{Pa}$ leozoic. For example, continental tillites occur in both the Proterozoic and Ordovician sections of the Taoudeni Basin in west Africa (Deynoux and Trompette, 1976; Deynoux et al., 1972).

Thick marine sections tend to contain the most complete history of advancing and retreating ice sheets, but generally do not record the beginning and end of a glacial event. An ice sheet may already have been in existence for several million years before its margin reaches sea level (e.g., the Cenozoic ice sheet in Antarctica), and an ice cap may survive for some time after the last recognizable marine glaciogenic sediments are deposited (Crowell, 1978). This can be a significant problem in dating Phanerozoic ice ages, although it is less important in the Proterozoic, for which less satisfactory age resolution is possible. In addition, it is possible that not all ice sheets originate in continental interiors, according to Denton and Hughes (1981), who proposed a controversial model in which the late Pleistocene ice domes of the northern hemisphere are thought to have originated as ice shelves over inland seas or embayments [but see Boulton (1979) for an opposing viewpoint].

Cenozoic climatic fluctuations have been inferred in great detail from the examination of the distribution of fossil taxa in oceanic deposits and from oxygen isotopic analysis of foraminifera and molluscs [summarized in Savin (1977) and Frakes (1979)]. During late Cenozoic time, glacial detritus was rafted and released by melting icebergs over vast areas of the ocean basins. A comparable climatic record is not available for most of Earth history because virtually all oceanic crust and sediment cover of preJurassic age has been subducted as a result of large-scale movements of lithospheric plates. Only scraps of this old oceanic crust are preserved as ophiolites in orogenic belts (Dewey and Bird, 1970). The pre-Jurassic record of ancient glaciation is therefore limited exclusively to the continental crust.

The chronology of glaciation prior to the Cenozoic has been established principally by a combination of paleontology and isotopic dating. However, fossils are generally rare in glaciogenic beds, and it is often difficult to relate nonmarine sections displaying the best evidence for glaciation to the worldwide time scale (Crowell, 1978). The problem becomes more acute in prePhanerozoic rocks. In spite of remarkable advances in the study of stromatolites (Hofmann, 1973; Walter, 1976: Awramik et al., 1979), their use in biostratigraphy is limited by their long age ranges, as well as by their environmental sensitivity. Microfossils may prove useful in dating latest Proterozoic glaciations, although Knoll et al. (1981) suggested that one supposed Vendian $(650-570$ Ma) form, Bavlinella faveolata, may be an indicator of glacially induced ecological stress. For Paleozoic beds, fossil ages are related to the isotopic time scale by direct correlation in many sequences (e.g., Harland et al., 1964; Harland and Francis, 1971; Van Eysinga, 1975). For pre-Phanerozoic rocks isotopic ages must come from 
the sequences in which the glacial strata are observed. In these cases, well-defined ages, such as those on basement, commonly provide only the coarsest bracketing. Ages on rocks within a particular sequence (e.g., K$\mathrm{Ar}$ and $\mathrm{Rb}-\mathrm{Sr}$ determinations on volcanic rocks, shale, or sedimentary minerals such as glauconite) are generally tentative and subject to significant errors.

In conclusion, the timing of ancient glaciation is uncertain as a result of an incomplete geologic record and the limited age resolution attainable. Although an overall chronology has been established, the times of initiation and termination of ice ages are mostly poorly known, and climatic fluctuations on the scale of glacial and interglacial intervals generally cannot be dated directly in pre-Cenozoic rocks.

\section{SUMMARY OF KNOWN ICE AGES}

\section{a. Archean (4.65-2.5 Ga)}

Archean terranes of low metamorphic grade (the greenstone belts) occur on all continents (Windley, 1977), but alleged tillites of this age are rare. Two reasonably well-dated examples of diamictites for which a glacial interpretation was suggested recently occur in Montana and South Africa, but in neither case is a glacial origin convincingly established.

Metadiamictite occurs in the wall-rocks of the Stillwater Complex in southwestern Montana, and has been dated as at least $2.75 \mathrm{Ga}$ old and possibly older than $3.14 \mathrm{Ga}$ [U-Pb determination on zircon; Nunes and Tilton (1971); Page (1977)]. The diamictite is locally as thick as $100 \mathrm{~m}$ and extends discontinuously along strike for more than 20 $\mathrm{km}$. The principal evidence for glacial activity cited by Page and Koski (1973) is the occurrence of supposed dropstones. I briefly examined the rocks in 1980 , and observed that the diamictite locally contains abundant deformed sedimentary fragments and that lonestones (isolated clasts) are associated with soft sediment deformation. Both features suggest emplacement on a pa- leoslope and ice rafting is not required to explain the lonestones. The glacial interpretation of these beds must therefore be regarded as possible but not proven.

Diamictite of the Witwatersrand Supergroup [2.7-2.6 Ga old; Van Njekirk and Burger (1978) was interpreted as tillite by Wiebols (1955)] and Fuller (1958), and a glacial origin was tentatively accepted by Frakes (1979) and Harland (198 1a, b). However, recent work by W. E. L. Minter (K. A. Eriksson, personal communication, July, 1981) suggests that the diamictite may represent nonglacial mudflows. A paleomagnetic study of the Ventersdorp lavas (2.6 Ga old), which overlie the Witwatersrand Supergroup, suggests that the diamictite was deposited at high latitude or prior to an interval of rapid apparent polar wander [see Fig. 1 of Piper (1976)]. However, paleomagnetic results from such ancient rocks are difficult to interpret, and the climatic significance of the Witwatersrand diamictite remains in doubt.

\section{b. Proterozoic (2.5-0.57 Ga)}

1. Early Proterozoic $(2.5-1.6 \mathrm{Ga}){ }^{3}$ Wellestablished tillites are known from two intervals in the Proterozoic. The older interval, best represented in North America, includes the Huronian Supergroup [2.5-2.1 $\mathrm{Ga}$; summarized by Roscoe (1973)] of Ontario and correlative sequences in Quebec, the Northwest Territories, Michigan, and Wyoming (Young, 1970, 1973; Long, 1974; Karlstrom and Houston, 1979). Huronian tillites occur in three groups separated by unconformities, and both terrestrial and marine facies are represented. Morris (1977a) obtained a paleolatitude of $35^{\circ}$ for the uppermost group of the Huronian (mean inclination of magnetization direction $\mathrm{A}=$ $54^{\circ}$ ). Higher paleolatitudes of $50-87^{\circ}$ [Symons (1975), and references in Steiner and Grillmair (1973)] probably correspond to a

\footnotetext{
${ }^{3}$ Lower, Middle, and Upper Proterozoic are used in the sense of Harrison and Peterman (1980) for intervals limited by ages of $2.5,1.6,0.9$, and $0.57 \mathrm{Ga}$.
} 
secondary magnetization or direction B of Morris (1977a).

Lower Proterozoic tillites also occur in the Griqualand West and Transvaal Basins of South Africa, where they have been dated as older than $2.2 \mathrm{Ga}$ [ $\mathrm{Rb}-\mathrm{Sr}$ isochron on andesite; Burger and Coertze (19731974)] and younger than the Ventersdorp lavas (Visser, 1971, 1981; De Villiers and Visser, 1977). The tillites appear to have been deposited at high paleolatitude (Piper, 1976, Fig. 1).

Diamictites recognized in the Bijawar Group of central India (Mathur, 1981) and in the Hamersley Basin of Australia (Trendall, 1976) are of questionable glacial origin and are only approximately dated as Early Proterozoic.

2. Middle to Late Proterozoic (1.6-0.57 $G a$ ). The younger interval of the Proterozoic with documented tillites extends from about $1 \mathrm{Ga}$ ago to Cambrian time (570 Ma). Glacial beds of this age are known from all continents with the possible exception of Antarctica [but see Neethling (1970), quoted by Crowell (1975)], and they occur mainly but not exclusively in marine basinal sections. Available age determinations appear to cluster into three groups: $\sim 1000$ $850 \mathrm{Ma}, \sim 820-740 \mathrm{Ma}$, and $\sim 655-575 \mathrm{Ma}$ (Williams, 1975a), and many sequences contain two major tillite units. However, the climatic significance of these widespread glacial beds has been very controversial, and it is appropriate in an overview of Earth's glacial history to discuss some of the disagreements.

In many marine sections, it is clear that some diamictite is probably nonglacial, a product of widespread continental rifting in Middle to Late Proterozoic time, and Schermerhorn (1974, 1975) has argued forcefully that the diamictite is mostly of tectonic rather than glacial origin. However, reappraisal of many of the alleged tillites during the last decade, including those deposited in continental interiors (Deynoux and Trompette, 1976), confirms most earlier interpretations of a significant glacial component and the need for substantial ice sheets [e.g., Blick (1979); Christie-Blick et al. (1980); and summarized in Hambrey and Harland (1981)]. One enigmatic feature of the tillites is their close association with carbonate rocks, including dolomite, normally considered an indicator of warm-water sedimentation (e.g., Spencer, 1971). Two explanations have been proposed. The first is that carbonates may be deposited in cold water (Carey and Ahmad, 1961: Bjørlykke et al., 1978), although the timing and conditions for dolomitization have not generally been established. A second explanation calls for rapid and extreme climatic fluctuations (Spencer, 1971; Williams, 1975a). Unfortunately, attempts at measuring paleotemperatures using stable-isotope geochemistry have produced equivocal results (Williams, 1979, 1981; Donnelly, 1981).

Perhaps the most problematic feature of the Middle to Upper Proterozoic tillites is the paleomagnetic evidence suggesting equatorial glaciation (Piper, 1973; Tarling, 1974; Morris, 1977b; McWilliams and McElhinny, 1980). Four explanations have been suggested. The first is that the timeaveraged position of the virtual geomagnetic pole does not approximate the geographic pole, although this is contrary to considerable Phanerozoic evidence (Runcorn, 1964; Briden and Irving, 1964; McElhinny, 1973; Drewry et al., 1974). A second explanation is that for these sedimentary rocks, the remnant magnetization measured significantly postdates the time of sedimentation, so that with sufficiently rapid plate motion (e.g., McElhinny et al., 1974), the tillites could have been deposited at higher latitudes (Crowell, 1975). However, this idea does not account for poles determined on igneous rocks, or for consistently low latitudes of thick sedimentary sections (e.g., McWilliams and McElhinny, 1980), and it does not appear to be rooted in any firm evidence. A third possibility is that there were two or three discrete, simultaneous, prolonged ice ages sufficiently extreme 
for ice sheets to advance into the tropics (Harland, 1964a,b). However, there is no evidence for the very large sea-level fluctuations (several hundreds of meters) that should have accompanied glacierization of most of the continents. In addition, such large ice sheets would have increased global albedo so much that it is debatable whether the ice would have melted again. A fourth explanation of the paleomagnetic results is that during late Proterozoic time, the Earth experienced an obliquity perturbation great enough $\left(\epsilon>54^{\circ}\right)$ for low and middle latitudes to be glaciated in preference to the poles (Williams, 1975a). The main difficulty with this hypothesis is the lack of firm evidence for obliquity radically different from the present at other times (although see Williams, 1972, 1973; Williams and Austin, 1973).

In summary, there is evidence for widespread glaciation during a span of about 400 $\mathrm{Ma}$ in Middle to Late Proterozoic time, with ice sheets extending to sea level, but the details of timing and the significance of the problematic paleomagnetic observations are yet to be worked out.

\section{c. Paleozoic $(570-230 \mathrm{Ma})^{4}$}

Evidence for glaciation is known principally from three intervals in the Paleozoic: Late Ordovician to Late Silurian (440-415 $\mathrm{Ma})$, latest Devonian (360-345 Ma), and Permo-Carboniferous (335-245 Ma). Ordovician tillites are best preserved in north and west Africa, where they are mainly of Ashgillian age (Beuf et al., 1971; Destombes, 1968; Deynoux et al., 1972; Deynoux and Trompette, 1981; Tucker and Reid, 1973). The ice sheet was located between the Saharan region and the Guinean Gulf. Upper Ordovician tillite also occurs in South Africa, with an ice sheet coming from the north and west (Rust, 1981). Late Ordovician glaciation in Africa may have persisted into the Early Silurian. However,

4 Absolute ages for the Phanerozoic are mainly from Van Eysinga (1975).
Silurian tillites occur principally in South America, where they range in age from Early Llandoverian in the Amazon Basin (Caputo et al., 1972; Carozzi, 1979) to Wenlockian in Bolivia, Peru, and Argentina (Crowell et al., 1980).

Evidence for Devonian glaciation is limited, but is best displayed in the Amazon Basin, where probable tillites are of Frasnian-Strunian age (Caputo et al., 1972; Carozzi, 1979).

The Late Paleozoic ice age is recorded on all the continents of Gondwana, namely, South America and the Falkland Islands, Africa and Madagascar, India, Australia, and Antarctica (Crowell and Frakes, 1975). The earliest evidence of this glaciation is found in Visean (Upper Mississippian) rocks of South America (Crowell, 1978). During Pennsylvanian time, ice centers developed in many parts of the then intact supercontinent, but by the Early Permian, glaciation had virtually ceased in South America. In contrast, Australian tillites are most widespread in the Early Permian (Crowell and Frakes, 1971), and on that continent there is evidence for ice rafting in rocks as young Kazanian (early Late Permian). The overall picture is one of many ice centers waxing and waning during a time span of about $90 \mathrm{Ma}$, but with the ice age lasting somewhat less than this at any particular locality.

Independent paleomagnetic data for the Ordovician-Permian interval have been interpreted in several somewhat different ways (McElhinny et al., 1974; Schmidt and Morris, 1977; Morel and Irving, 1978), but indicate that ice centers formed preferentially at high paleolatitude [mostly within $30-40^{\circ}$ of the south pole; Scotese et al. (1979)]. The progression in ages of tillites from Ordovician in North Africa to Permian in Australia roughly corresponds to the apparent wander path of the virtual geomagnetic pole.

\section{d. Cenozoic (65-0 Ma)}

The earliest direct evidence of Cenozoic 
glaciation in the southern hemisphere consists of Upper Oligocene(?) (26 Ma) glaciomarine sediments in the Ross Sea (Hayes and Frakes, 1975; Barrett, 1975) and in the northern hemisphere of Middle Miocene sediment in the Gulf of Alaska (Plafker and Addicott, 1976). Geitzenauer et al. (1968) and Margolis and Kennett (1971) interpreted sand grains in South Pacific sediments, thought to be of Early Eocene age, as ice-rafted, but this suggestion is not corroborated by apparently low temperature gradients near Antarctica [discussion in Frakes (1979)]. From analysis of D.S.D.P. samples in the southern ocean, Lazarus and Hayes (1981) concluded that ice rafting was insignificant before the Pliocene. Presumably, however, a substantial ice sheet already existed in Antarctica for several million years prior to the arrival of ice at sea level around much of the continent. Corroboration for this, in addition to the Ross Sea evidence already mentioned, is the rapid sea-level fall, indicated by the marked Late Oligocene (29 Ma) seaward shift in coastal onlap observed in seismic profiles from many parts of the world (Vail and Hardenbol, 1979; and Fig. 2). Details of climatic fluctuations during the late Cenozoic Ice Age are reviewed elsewhere in this volume (Imbrie, 1982).

\section{RELATIVE SIGNIFICANCE OF ICE AGES}

It would be desirable in an evaluation of Earth's climatic history to assess the relative significance of the ice ages, but, unfortunately, a quantitative comparison is difficult in part for reasons already discussed in the section on dating glacial events. Possible criteria that might be used to compare ice ages are the areal extent of former ice sheets inferred from the paleogeographic reconstruction of glacial deposits, the lengths of ice ages, the thickness of deposits, paleolatitudes of tillites, and the magnitudes of glacioeustatic changes in sea level. However, none of these criteria is particularly reliable.

Paleogeographic reconstruction was used to locate Permo-Carboniferous ice sheets with some success by Crowell and Frakes [(1975), and in a succession of papers dealing with each of the Gondwana continents]. However, the size of ice sheets is difficult to estimate even with widely distributed deposits. With worse age resolution and an even more fragmentary record, typical of the Proterozoic ice ages, it becomes virtually impossible to reconstruct ice sheets at any particular time. Similarly, the lengths of ice ages are not well known in prePermo-Carboniferous rocks, and it is likely, for example, that several distinct Proterozoic events are currently not resolved by the few dates available. Moreover, both the lengths of ice ages and the areal distribution of deposits are likely to be measures of the paleolatitudinal position of continents rather than purely a function of global climate. The thickness of deposits indicates subsidence and sedimentation rates rather than the scale of glaciation. Sedimentation rates can vary by several orders of magnitude from a few meters per million years in some nonmarine deposits to 1000 $\mathrm{m} / \mathrm{Ma}$ in the Gulf of Alaska, for example (Plafker and Addicott, 1976). Isolated paleomagnetic determinations of tillite paleolatitude do not constitute a good indicator of the scale of glaciation because the growth of ice sheets is very much influenced by geographic factors affecting precipitation, such as the distribution of land and sea, patterns of atmospheric circulation, and topography. Furthermore, it is not clear that the enigmatic low paleomagnetic latitudes associated with some Proterozoic tillites necessarily reflect global climates colder than those during other ice ages. Finally, glacioeustatic changes in sea level are distinguished with difficulty from other nonglacial eustatic controls or from more local changes in the rates of subsidence and sedimentation that affect relative sea level. In this regard, seismic stratigraphy (Vail et al., 1977a) has revolutionized the analysis of eustatic sea-level changes, especially for Mesozoic and Cenozoic time. 


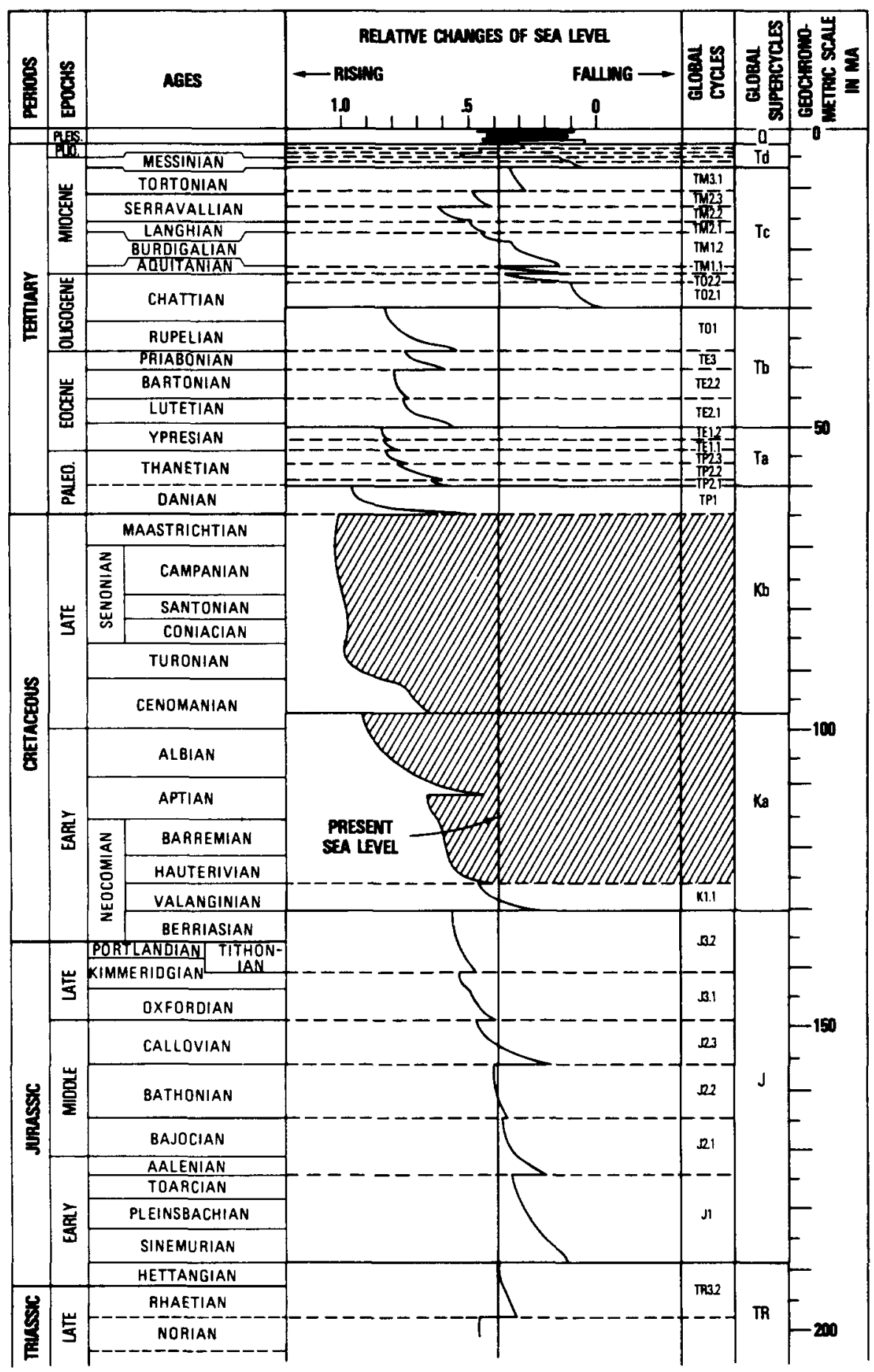

Fig. 2. Chart of global relative changes of sea level since the Triassic as indicated by relative changes of coastal onlap. Cretaceous cycles (hatchured area) have not been released for publication (Vail et al., 1977b). 


\section{INTERVALS WITHOUT IMPORTANT GLACIATION}

There appear to be three intervals in Earth history for which there is minimal or no evidence for glaciation. These are: (1) from the age of the oldest known rocks at about $4 \mathrm{Ga}$ to around $2.5 \mathrm{Ga}$ ago; (2) from $2.1 \mathrm{Ga}$ to approximately $1 \mathrm{Ga}$ ago; and (3) from $245 \mathrm{Ma}$ to $26 \mathrm{Ma}$ ago or slightly earlier.

\section{a. Archean Interval $(4-2.5 \mathrm{Ga})$}

There are few climatic indicators in sedimentary rocks older than $2.5 \mathrm{Ga}$ and few magnetic data with which to determine paleolatitudes. Knauth and Epstein (1976) used stable-isotope geochemistry to infer pre-Phanerozoic paleotemperatures as high as $70^{\circ} \mathrm{C}$ for 3-Ga-old cherts in South Africa. However, it is not clear to what extent measured isotopic ratios reflect Archean oceanic temperature, the Archean isotopic composition of sea water, or the effects of later diagenesis, hydrothermal alteration, metamorphism, and isotopic exchange with meteoric water over geologic time (Perry and Tan, 1972; Knauth and Epstein, 1976). On the other hand, a paleotemperature of $70^{\circ} \mathrm{C}$ is not incompatible with the probable temperature tolerances of Archean living organisms (Knauth and Epstein, 1976).

From a theoretical standpoint, Archean climate would have been strongly controlled by solar luminosity and by atmospheric composition. In spite of questions raised by the low neutrino flux observed from the Sun, Newkirk (1980) regards the theory of stellar evolution-which predicts a solar luminosity $4.6 \mathrm{Ga}$ ago of about $70 \%$ its contemporary value-as robust. For current albedos and atmospheric composition, the global mean temperature of the Earth would have been less than the freezing point of water about $2 \mathrm{Ga}$ ago. The absence of evidence for widespread Archean glaciation is probably best explained by considering the greenhouse effect of a primitive atmosphere composed of $\mathrm{CH}_{4}$ and
$\mathrm{NH}_{3}$ or $\mathrm{CO}_{2}-\mathrm{H}_{2} \mathrm{O}$ cloud (Sagan and Mullen, 1972; Sagan, 1977; Walker, 1976, 1977; Hart, 1978; Owen et al., 1979; and Pollack, 1979). However, a considerable range of climates may be envisaged for the early Earth, and it is possible that evidence for Archean glaciation has simply been mostly or completely eradicated.

\section{b. Early to Middle Proterozoic Interval $(2 . l-l .0 \mathrm{Ga})$}

The interval from 2.1 to $1.0 \mathrm{Ga}$ is characterized by the presence of abundant carbonate rocks (Ronov, 1964), suggestive of warm-water marine sedimentation, and widespread evaporites, consistent with locally hot dry climates. Chert geothermometry suggests paleotemperatures in the range $20-52^{\circ} \mathrm{C}$ (Knauth and Epstein, 1976). Available paleomagnetic data indicate that several continents experienced large latitudinal shifts and at different times occupied both polar and equatorial positions (Irving and McGlynn, 1976; Piper, 1976; Morris, 1977a). The absence of evidence for glaciation during this long interval therefore suggests a period of persistently warm climate on a global scale.

\section{c. Late Permian to Mid-Cenozoic Interval (245-26 Ma)}

The distribution of climatically sensitive sedimentary rocks on paleomagnetically repositioned continents (Drewry et al., 1974), the absence of tillites, the wide latitudinal ranges of invertebrate and plant fossils, and stable-isotope geothermometry suggest a globally equable climate for the entire interval from Late Permian to early Cenozoic [summarized by Frakes (1979)]. Isolated stones, possibly dropstones, occur in Jurassic and Cretaceous deposits of northern Siberia, in the Cretaceous of Svalbard, Alaska, and New Zealand, and in Paleogene sediments of Svalbard, the U.S.S.R., and New Zealand, all these regions located at high paleolatitude [summarized in Hambrey and Harland (1981) and Collins (1961)]. Some of the stones may 
have been rafted by sea ice, but there is no direct evidence for significant glaciation. The mid-Jurassic so-called Mawson Tillite of Antarctica (Warren, 1962) is probably a nonglacial volcanic breccia (Borns and Hall, 1969).

In conflict with the impressive evidence favoring generally warm climates during the Mesozoic and Paleogene are some globally synchronous and rapid shifts in coastal onlap, determined by seismic stratigraphy, that suggest sea level fluctuations that are in part glacially controlled, because the rates involved appear to be too rapid for tectonic mechanisms alone (Vail et al., 1977b; Vail and Hardenbol, 1979; Kerr, 1980; and Fig. 2). Most of the ice responsible must have been situated in Antarctica, consistently positioned at high latitude, because this is the only large continent where the evidence can remain effectively hidden. Two important limitations on the size of a possible ice sheet are that it did not spread onto still attached fragments of Gondwana and that it probably did not reach sea level. The latter is indicated by relatively warm oceanic bottom water (Savin, 1977) and by the apparent absence of rafted detritus in oceanic sediments of Mesozoic age. The present Antarctic ice sheet is equivalent to about 55 $m$ of water spread over the world ocean (Denton et al., 1971), suggesting that a Mesozoic ice sheet would have been equivalent to somewhat less than $50 \mathrm{~m}$ of water. A significant aspect of the seismic evidence is that the presence of even a small ice cap during the demonstrably warm Mesozoic Era suggests that an ice sheet may have been a relatively persistent feature near the south pole throughout the Phanerozoic.

\section{PERIODIC AND EPISODIC CLIMATIC FLUCTUATIONS ON EARTH}

Several authors have suggested that terrestrial ice ages occur periodically either once or twice per cosmic year, the time required for the Sun to execute one orbit around the center of the galaxy (Umbgrove, 1947; Steiner, 1967; Steiner and Grillmair,
1973; Williams, 1975b; Mitchell, 1976). For example, Steiner (1967) proposed a model for producing variable solar luminosity based on the idea that the universal gravitational "constant" $(G)$ is a function of time and space. According to the model, solar luminosity varies because the Sun experiences a variable gravitational function in its elliptical orbit. Ice ages supposedly occur once per cosmic year [280 Ma in Steiner (1967)], when the Sun is at the perigalacticum, or closest to the galactic center (approximately its current location). Another model, which predicts ice ages with the same periodicity, invokes temporary variation in the Sun's radiation during passage of the solar system through interstellar clouds in the spiral arms of the galaxy (e.g., McCrea, 1975; Talbot et al., 1976). Williams (1975b) suggested that ice ages have occurred with a period of about $155 \mathrm{Ma}$ since the Late Proterozoic, or twice per cosmic year (estimated as $303_{-51}^{+65} \mathrm{Ma}$ ). In his model, solar luminosity is reduced twice per orbit as the Sun passes through diametrically opposite galactic flexures (Table I). Steiner and Grillmair (1973) obtained a better fit between the timing of ice ages and the cosmic year by cunningly abandoning strict periodicity. In their model, the Sun spirals inward in such a way that the duration of the cosmic year decreases from $400 \mathrm{Ma}$ in the Archean to $280 \mathrm{Ma}$ today.

The inferred timing of ice ages and times predicted by the models of Williams (1975b) and Steiner and Grillmair (1973) are shown in Table I. It is clear from both Table I and Fig. 1 that the occurrence of ice ages is not strictly periodic, and even focusing only on the last $1 \mathrm{Ga}$, Williams (1975b) incorrectly predicts significant glaciation at $145 \mathrm{Ma}$ ago (latest Jurassic). Steiner and Grillmair (1973) account for the glacial history of the last $1 \mathrm{Ga}$, but incorrectly predict ice ages at $1119,1489,1873,2660$, and $3060 \mathrm{Ma}$ for which there is no evidence. On the other hand, major ice ages do appear to occur episodically with a charactertistic time of $10^{8}-10^{9}$ years, requiring overall controls on 
TABLE I

Comparison of Timing of Major Ice Ages and Quasi-Periodic Solar Orbital Parameters Suggested by Williams (1975b) and Steiner and Grillmair (1973)

\begin{tabular}{|c|c|c|c|c|}
\hline \multicolumn{3}{|c|}{ Timing of ice ages (Ma) } & \multirow{2}{*}{$\begin{array}{c}\text { Timing of } \\
\text { solar orbital } \\
\text { parameter (Ma) } \\
\text { Williams (1975b) }\end{array}$} & \multirow{2}{*}{$\begin{array}{c}\text { Timing of } \\
\text { solar } \\
\text { apsides (Ma) } \\
\text { Steiner and } \\
\text { Grillmair (1973) }\end{array}$} \\
\hline This paper & Williams (1975b) & $\begin{array}{c}\text { Steiner and } \\
\text { Grillmair (1973) }\end{array}$ & & \\
\hline $13 \pm 13$ & $-10 \pm 30$ & $7 \pm 7$ & $\begin{array}{r}-10 \\
145\end{array}$ & $-8 \pm 4$ \\
\hline $\begin{array}{l}290 \pm 45 \\
352 \pm 7\end{array}$ & $295 \pm 55$ & $288 \pm 55$ & 300 & 280 \\
\hline $427 \pm 12$ & $445 \pm 5$ & $440 \pm 40$ & 455 & 437 \\
\hline $615 \pm 40$ & $615 \pm 40$ & $616 \pm 30$ & 610 & 595 \\
\hline $780 \pm 40$ & $770_{-30}^{+50}$ & $777 \pm 40$ & 765 & 766 \\
\hline \multirow[t]{3}{*}{$925 \pm 75$} & \multirow[t]{3}{*}{$940+80$} & \multirow[t]{3}{*}{$950 \pm 50$} & \multirow[t]{3}{*}{920} & 937 \\
\hline & & & & $\begin{array}{l}1119 \\
1489\end{array}$ \\
\hline & & & & 1873 \\
\hline \multirow[t]{3}{*}{$2300 \pm 200$} & & \multirow[t]{3}{*}{$2288 \pm 87$} & & 2265 \\
\hline & & & & 2660 \\
\hline & & & & 3060 \\
\hline
\end{tabular}

the Earth's climate that are effective on the same time scale (Mitchell, 1976). Among these are possible periodic and merely episodic variations in solar output, long-term changes in atmospheric composition, and the rearrangement of continents and oceans brought about by the movement of lithospheric plates (Crowell and Frakes, 1970; Pollack, 1979). Since several controls are significant on this time scale, and since the controls are probably largely stochastic, it is hardly surprising that the resulting climatic variation is not periodic.

Climatic variations with characteristic times of $10^{6}-10^{7}$ years are indicated by several lines of evidence. Dorman (1968) proposed a 30-Ma periodicity in global temperatures based on oxygen isotope analyses of Cenozoic molluscs. Fischer and Arthur (1977) suggested that the expansion and decline of diversity in Mesozoic and Cenozoic pelagic marine organisms, on a time scale of $32 \mathrm{Ma}$, was in some way related to climate change. Equivalent but less regular events appear to have characterized the Paleozoic seas on a time scale of 4-46 Ma (Leggett et al., 1981). Examination of the Mesozoic and Cenozoic chart of global relative changes in sea level (Fig. 2; Vail et al., 1977b) suggests episodic, abrupt glacioeustatic lowering of sea level with a characteristic time of 1-10 Ma. Among possible primary controls for these climatic variations are changes in atmospheric composition (Fischer, 1982a), tectonism, and variations in solar output, although effective feedback mechanisms are definitely required to explain the apparently rapid growth and disintegration of small ice sheets in the generally warm Mesozoic.

An explanation for the waxing and waning of Pleistocene ice sheets on a time scale of $10^{4}-10^{5}$ years has long been sought in a variety of factors, such as variations in solar output, the absorption of solar energy by interstellar dust, in the seasonal and latitudinal distribution of incident radiation due to changes in the Earth's orbital parameters, atmospheric dust, and in the Earth's magnetic field [summarized by Hays et al. (1976)]. The application of time series analysis to the climatic record in deep sea cores 
has now demonstrated that glacial and interglacial stages can be largely, although not completely, explained by orbital perturbations (Hays et al., 1976; Imbrie and Imbrie, 1980; and Imbrie, 1982). The most important periodicities are 413, 100, 41, 23, and $19 \mathrm{Ka}$. Observations in many welldated rhythmically bedded sedimentary sequences, ranging in age from latest Proterozoic to Cretaceous, suggest that periodic orbital variations may have affected climate for at least the entire Phanerozoic (Arthur, 1979; Fischer, 1980, 1982a, b). However, the relative importance of the various orbital parameters in controlling climate has probably varied through geologic time (Fischer, 1982a; Ward, 1982).

\section{GEOLOGY OF MARS AND EVIDENCE FOR CLIMATE CHANGE}

Mars is divided into two morphologically distinct hemispheres by a great circle intersecting the equator at roughly $35^{\circ}$ (Mutch et al., 1976). The southern hemisphere is dominated by cratered terrain and basins, probably older than $3.8 \mathrm{Ga}$ (Head and Solomon, 1981), although there is abundant evidence for continued volcanic modification of the surface following the period of heavy bombardment early in Martian history. Much of the northern hemisphere consists of plains of lower elevation, underlain by volcanic lava, but punctuated by giant shield volcanoes. The most prominent of these are concentrated in the Tharsis plateau, $4000 \mathrm{~km}$ in diameter and rising more than $10 \mathrm{~km}$ above Mars datum (Head and Solomon, 1981). The principal evidence suggesting that significant climate changes have occurred on Mars consists of widespread dry channels and of geologically young rhythmically layered terrains in the polar regions (Pollack, 1979).

\section{a. Channels}

Channels observed on Mars range in scale from on the order of $10^{3} \mathrm{~km}$ long and $10^{2} \mathrm{~km}$ wide to $10 \mathrm{~km}$ long and $1 \mathrm{~km}$ wide (Sharp and Malin, 1975). Their ages are not well established, but analysis of cratering statistics suggests that most channels formed over an extended period some time between 3.5 and $0.5 \mathrm{Ga}$ ago (Masursky et al., 1977). The smallest channels, termed gullies by Pieri (1976), are common over much of Mars, but appear to be absent on the youngest geologic features, such as Tharsis. Morphologic contrasts suggest that channels are of several different origins (Sharp and Malin, 1975), but most explanations require that past climatic conditions on Mars were quite unlike those of today.

Morphologic features such as dendritic patterns, sinuosity, and braiding suggest that some of the channels were cut by running water, although liquid water is not now stable on the Martian surface (Sagan et al., 1973; Sharp and Malin, 1975; Masursky et al., 1977). Gullies constitute the best evidence for rainfall or atmospherically induced melting of permafrost (Pollack, 1979). They are ubiquitous in both craterfree terrain and on crater rims in areas lacking much evidence for volcanic activity, and are thus not a result of the melting of permafrost by volcanism or meteoritic impact.

The origin of the largest channels, termed outflow channels by Sharp and Malin (1975), is controversial (Cutts and Blasius, 1981). One possibility is that they were cut by catastrophic floods resulting from the sudden release of subsurface water (e.g., Masursky et al., 1977; Carr, 1979). However, Nummedal (1978) suggested that the outflow channels were eroded by debris flows, and Cutts and Blasius (1981) proposed an eolian model. Whatever the process, it does not seem to be operative on Mars now.

\section{b. Polar Layered Terrains}

The polar regions of Mars are underlain by extensive layered terrains consisting of wind-blown dust and water-ice (Cutts, 1973). These deposits are among the youngest features of the Martian surface, because fresh impact craters are absent (Cutts et al., 
1976). The layering appears to be climatically induced and related to pronounced variations in the orbital parameters of Mars on a time scale of $10^{5}-10^{6}$ years (Ward, 1974, 1979; Pollack, 1979; Toon et al., 1982). If this is true, the layered terrains could have accumulated in only a few million years.

Several models have been proposed to account for the stratigraphic, topographic, and geomorphic characteristics of the polar deposits. These include the suggestion that dust was deposited during a single event (Cutts, 1973), models in which dust accumulates contemporaneously with ice ablation (Howard, 1978; Squyres, 1979; Toon et al., 1982; Howard et al., 1982), and models involving episodic accumulation of dust and ice (Cutts et al., 1976, 1979; Cutts and Lewis, 1982). However, none of the hypotheses yet explains all the observed characteristics of the layered terrains (Blasius $e t$ al., 1982).

\section{DISCUSSION: IMPLICATIONS OF \\ TERRESTRIAL RECORD OF ICE AGES TO ANCIENT CLIMATIC HISTORY OF MARS}

The geologic record and controls of climatic change on Earth are now reasonably well known, and some progress can be made toward understanding ancient Martian climatic history by means of a comparison of the two planets (e.g., Pollack, 1979).

Let us consider, for example, the possible characteristics of fossil polar layered terrains on Mars and the likelihood that such deposits would be preserved. The recognition of ancient glaciation on Earth is based on the identification of erosional features and deposits generated by glacial activity. The sedimentary product of the climatically induced disintegration of a Martian polar terrain would be quite unlike its terrestrial counterpart and potential characteristics would depend largely on the mechanism of "deglaciation." Under the present atmospheric pressure of only a few millibars, ice sublimes rather than melts. Hence the degree to which primary layering might be preserved under conditions of low atmospheric pressure would depend on whether dust liberated from the ice was subsequently recycled by eolian activity or effectively buried. Toon et al. (1982) have shown that water-ice could melt in windsheltered regions during times of high orbital obliquity if atmospheric pressure were substantially increased. This suggests that another possible product of the disintegration of polar layered terrains would be analogous to outwash on Earth, but much finer grained. Howard (1982) has interpreted narrow braided ridges conspicuous in the south polar region of Mars as possible eskers, that is, fluvial sediments resulting from the basal melting of a thick ice cover, now ablated.

In contrast to ice sheets on Earth, Martian ice caps do not appear to flow, and it has been assumed in the above discussion that ancient polar terrains were similar to present ones. It is not clear whether earlier layered terrains could have flowed and slid over their substrates, but such behavior could have led to basal erosion and produced glacial deposits more similar to terrestrial ones. Possible controls on the tendency of polar terrains to flow are: (1) composition (e.g., the relative proportions of dust, water-ice, and $\mathrm{CO}_{2}$-ice); (2) layering characteristics; (3) the total thickness of deposits [inferred to be currently $1-2 \mathrm{~km}$ in the south and 4-6 km in the north: Dzurisin and Blasius, (1975)]; (4) lateral extent [currently about $10^{\circ}$ of latitude in the northern hemisphere; Cutts et al. (1979)]; (5) surface temperature [estimated to be $205^{\circ} \mathrm{K}$ in late summer near the north pole; Kieffer et al. (1976)]; and (6) gravitational acceleration [371 gals on Mars, in comparison with 980 gals for the Earth; Mutch et al. (1976)].

The terrestrial lithosphere has been relatively mobile for much of Earth history and evidence for high-latitude glaciation is distributed over all the continents, even those now in equatorial positions. In comparison, large-scale lateral movements between lithospheric blocks do not seem to have occurred on Mars (Head and Solomon, 1981). 
However, two lines of evidence suggest that polar wandering may have taken place relative to the whole lithosphere. The first is the observation of unique arcuate structures near the north pole of Mars (Murray and Malin, 1973). The second is the observation of layered terrains near the Martian equator that are strikingly similar to polar deposits, and may indicate former pole positions (Schultz and Lutz-Garihan, 1981). If polar wandering has occurred on Mars, ancient polar deposits should be sought on all parts of the planet, not merely near the present poles.

On Earth, vertical tectonics affects climate by influencing atmospheric circulation. Mars is sufficiently small that largescale vertical tectonics, such as that associated with the Tharsis region, may have distorted the lithosphere sufficiently to affect axial obliquity (Ward et al., 1979). It is therefore possible that changes in Martian climate could have been triggered by major tectonic events, since climate seems to be strongly affected by obliquity.

The link between periodic changes in orbital parameters and quasi-periodic climatic fluctuations on Earth is now so convincingly established by evidence from the ocean floor (Imbrie, 1982) that an analogous explanation for layering in polar terrains on Mars seems very credible. This is perhaps the most important implication of the terrestrial record of ice ages to the climatic history of Mars.

Finally, I will mention the importance of possible long-term changes in planetary atmospheres and solar luminosity to the evolution of climate. The initiation of glaciation on Earth between 2.5 and $2.1 \mathrm{Ga}$ ago appears to have been due, at least in part, to a gradual shift in the balance between a progressive decrease in the effect of the atmospheric greenhouse and increasing solar luminosity. The same controls were probably operative on Mars, although the Martian greenhouse effect was probably reduced by the lowering of atmospheric pressure, as well as by a change in atmospheric compo- sition (Pollack, 1979). The time at which polar ice caps first formed on Mars may have been quite different from the time at which this event occurred on Earth. However, in view of Earth's long history of episodic glaciation, it would be surprising if polar ice caps had existed on Mars for only a few million years.

\section{SUMMARY}

Ice ages have occurred episodically on Earth during at least the latter $50 \%$ of its history, and a small ice sheet may have been a persistent feature near the south pole throughout the last $500 \mathrm{Ma}$. Major glacial events are known from the Early Proterozoic, several intervals of the Middle to Late Proterozoic, the Ordovician-Silurian, possibly latest Devonian, Permo-Carboniferous, and late Cenozoic. A generally warm climate seems to have prevailed during the Archean, much of the Early to Middle Proterozoic, and the Mesozoic to early Cenozoic.

On Earth, climatic fluctuations occur on several time scales, but only those driven by perturbations of the Earth's orbital parameters on a time scale of $10^{4}-10^{5}$ years are demonstrably periodic. The occurrence of ice ages with a characteristic time of $10^{8}$ $10^{9}$ years is explicable in terms of predicted variations in solar output, inferred changes in atmospheric composition, and the rearrangement of continents and oceans resulting from the movement of lithospheric plates. Controls for climatic variations on a time scale of $10^{6}-10^{7}$ years are less well understood, but may also be related to atmospheric composition, tectonism, and variations in solar output.

An appreciation of the geological record and possible causes of ancient ice ages on Earth suggests nonuniformitarian as well as uniformitarian ways of thinking about ancient climates on Mars. Fossil polar layered terrains could be preserved if the ice component sublimed and layering within the dust was not destroyed by eolian activity. Melting of polar terrains under conditions 
of greater atmospheric pressure would produce outwash deposits analogous to those of Earth. Martian ice caps do not appear to flow or slide now, but it is possible that they did in the past, and this could have produced glacial deposits still more similar to those of Earth. The Martian lithosphere is relatively stable, but if polar wander has occurred, ancient polar deposits should be sought on all parts of the planet, not merely near the present poles.

Abrupt changes in Martian climate may have been triggered by major tectonic events through changes induced in planetary obliquity. Periodic climate changes, such as suggested by layering in the polar terrains, seem to be due to more regular fluctuations in the orbital parameters. Polar ice caps probably first formed on Mars as a result of a gradual shift in the balance between a progressive decrease in the effect of the atmospheric greenhouse and increasing solar luminosity. By analogy with the Earth, polar layered terrains have probably existed episodically on Mars for a considerable time, but observational evidence supporting this idea still needs to be assembled.

\section{AC KNOWLEDGMENTS}

I thank K. T. Biddle, M. V. Caputo, J. C. Crowell, J. A. Cutts, W. B. Harland, J. M. G. Miller, and P. D. Snavely III for critical reviews of this paper. J. A. Cutts was especially helpful with his comments on Martian climate and in supplying several pertinent references. Exxon Production Research Company approved publication and allowed me to attend the NASA-sponsored "Workshop on Quasi-Periodic Climatic Changes on Earth and Mars," which lead to the paper being written. Ideas presented are in part the product of doctoral and postdoctoral studies completed at the University of California, Santa Barbara, supported by NSF Grants ATM 74-24201, EAR 7706008, and EAR 78-15194 to J. C. Crowell. N. J. Page kindly pointed out in correspondence the best exposures for examining diamictite in the wall rocks of the Stillwater Complex, which I visited in July 1980. I thank A. G. Fischer for a preprint of his paper on longterm climatic oscillations.

\section{REFERENCES}

ANdersen, B. G. (1981). Late Weichselian ice sheets in Eurasia and Greenland. In The Last Great Ice
Sheets (G. H. Denton and T. J. Hughes, Eds.), pp. 1-65. Wiley, New York.

ANDERSON, J. B., D. D. Kurtz, E. W. DOMACK, AND K. M. BALshaW (1981). Glacial and glacial marine sediments of the Antarctic continental shelf. $J$. Geol. 88, 399-414.

Arthur, M. A. (1979). Sedimentologic and Geochemical Studies of Cretaceous and Paleogene Pelagic Sedimentary Rocks: The Gubbio Sequence. Ph.D. dissertation, Part I, Princeton University, Princeton, N.J.

Awramik, S. M., A. Haupt, H. J. Hofmann, and M. R. WALter (1979). Stromatolite bibliography 2 . Precambrian Res. 9, 105-166.

BarretT, P. J. (1975). Textural characteristics of Cenozoic preglacial and glacial sediments at site 270 . Ross Sea, Antarctica. In Initial Reports of the Deep Sea Drilling Project 28, pp. 757-766. U.S. Govt. Printing Office, Washington, D.C.

Barron, E. J., S. L. Thompson, AND S. H. SCHNEIDER (1981). An ice-free Cretaceous? Results from climate model simulations. Science 212, $501-508$.

Beuf, S., B. Buu-Duval, O. De Charpal, P. Rognon, O. Gariel. And A. Bennacef (1971). Les grès du Paléozoique Inferieur au Sahara. L'Institute Français du Pétrole, Paris.

BjørlykKe, K., B. BUe, AND A. ElverhøI (1978). Quaternary sediments in the northwestern part of the Barents Sea and their relation to the underlying Mesozoic bedrock. Sedimentology 25, 227-246.

Blasius, K. R., J. A. CUTtS, AND A. D. Howard (1982). Topography and stratigraphy of Martian polar layered deposits. Icarus 50, 139-159.

Bu.ıck, N. H. (1979). Stratigraphic, Structural and Paleogeographic Interpretation of Upper Proterozoic Glaciogenic Rocks in the Sevier Orogenic Belt, Northwestern Utah. Ph.D. dissertation, University of California, Santa Barbara.

Borns, H. W., JR., AND B. A. Hall (1969). Mawson "Tillite" in Antarctica: Preliminary report of a volcanic deposit of Jurassic age. Science 166, 870-872.

Boulton, G. S. (1972). Modern Arctic glaciers as depositional models for former ice sheets. J. Geol. Soc. London 128, 361-393.

Boulton, G. S. (1975). Processes and patterns of subglacial sedimentation: A theoretical approach. In Ice Ages: Ancient and Modern (A. E. Wright and F. Moseley, Eds.), pp. 7-42. Seel House Press, Liverpool.

Boulton, G. S. (1976). A genetic classification of tills and criteria for distinguishing tills of different origin. Geografia 12, 65-80.

Boulton, G. S. (1979). A model of Weichselian glacier variation in the North Atlantic region. Boreas 8 , 373-395.

Boulton, G. S. (1980). Till species-Terminology and criteria for recognition. Quat. Nen'sl. No. 31. 
Boulton, G. S., A. S. Jones, K. M. Clayton, and M. J. KenNing (1977), A British ice-sheet model and patterns of glacial erosion and deposition in Britain. In British Quaternary Studies: Recent Advances (F. W. Shotton. Ed.), pp. 231-246. Oxford Univ. Press (Clarendon), London/New York.

Briden, J. C., And E. Irving (1964). Palaeolatitude spectra of sedimentary palaeoclimatic indicators. In Problems in Palaeoclimatology (A. E. M. Nairn, Ed.), pp. 199-224. Interscience, New York.

Burger, A. J., And F. J. Coertze (1973-1974). Age determinations, April 1972 to March 1974. Annu. Geol. Surv. S. Afr. 10, 135-141.

Caputo, M. V., R. Rodrigues, and D. N. N. De VASCONCELOS (1972). Nomenclatura estratigráfica da bacia do Amazonas histórico e atualização. $A n$ XXVI Congr. Bras. Geol. Soc. Bras. Geol. 3, 35-46.

Carey, S. W., and N. Ahmad (1961). Glacial marine sedimentation. In Geology of the Arctic (G. O. Raasch, Ed.), Vol. 2, pp. 865-894. Univ. Toronto Press, Toronto.

CArozzi, A. V. (1979). Petroleum geology in the Paleozoic clastics of the Middle Amazon Basin, Brazil. J. Pet. Geol. 2, 55-74.

CARr, M. H. (1979). Formation of Martian flood features by release of water from confined aquifers. $J$. Geophys. Res. 84, 2995-3007.

Christie-Blick, N., P. K. Link, J. M. G. Miller, G. M. Young, and J. C. Crowell (1980). Regional geologic events inferred from upper Proterozoic rocks of the North American Cordillera. Geol. Soc. Amer. Abstr. Progr. 12, No. 7, 402.

Collins, F. R. (1961). Core tests and test wells, Barrow area, Alaska. U.S. Geol. Surv. Prof. Pap. 305K, 569-641.

Crittenden, M. D., B. J. Sharp, and F. C. Calkins (1952). Geology of the Wasatch Mountains east of Salt Lake City, Parleys Canyon to Traverse Range. In Geology of the Central Wasatch Mountains (R. E. Marsell, Ed.), pp. 1-37. Utah Geol. Min. Surv. Guidebook No. 8.

Crittenden, M. D., JR., J. H. Stewart, and C. A. WALLACE (1972). Regional correlation of upper Precambrian strata in western North America. 24t h Int. Geol. Congr. Rep. Sect. 1, 334-341.

Crowell, J. C. (1957). Origin of pebbly mudstones. Geol. Soc. Amer. Bull. 68, 993-1010.

Crowell, J. C. (1964). Climatic significance of sedimentary deposits containing dispersed megaclasts. In Problems in Palaeoclimatology (A. E. M. Nairn, Ed.), pp. 86-99. Interscience, New York.

Crowell, J. C. (1975). The significance of glaciations in Precambrian correlation. In Symposium on the Correlation of the Precambrian. Int. Geol. Corr. Progr., Moscow.

Crowell, J. C. (1978). Gondwanan glaciation, cyclothems, continental positioning, and climate change. Amer. J. Sci. 278, 1345-1372.
Crowell, J. C., ANd L. A. Frakes (1970). Phanerozoic glaciation and the causes of ice ages. Amer. $J$. Sci. 268, 193-224.

Crowell, J. C., AND L. A. Frakes (1971). Late Paleozoic glaciation: Part IV, Australia. Geol. Soc. Amer. Bull. 82, 2515-2540.

Crowell, J. C., And L. A. Frakes (1975). The Late Paleozoic glaciation. In Gondwana Geology (K. S. W. Campbell, Ed.), pp. 313-331. Australian National Univ. Press, Canberra.

Crowell, J. C., A. C. Rocha-Campos, and R. SuÁrez-Soruco (1980). Silurian glaciation in central South America. In Gondwana Five (M. M. Cresswell and P. Vella, Eds.), pp. 105-110. A. A. Balkema, Rotterdam.

Cutts, J. A. (1973). Nature and origin of layered deposits of the Martian polar regions. J. Geophys. Res. 78, 4231-4249.

Cutts, J. A., and K. R. Blasius (1981). Origin of Martian outflow channels: The eolian hypothesis. $J$. Geophys. Res. 86, 5075-5102.

Cutrs, J. A., AND B. H. Lewis (1982). Models of climate cycles recorded in Martian polar layered deposits. Icarus 50, 216-244.

Cutts, J. A., K. R. Blasius, G. A. Briggs, M. H. Carr, R. Greeley, and H. Masursky (1976). North polar region of Mars: Imaging results from Viking 2. Science 194, 1329-1337.

Cutts, J. A., K. R. Blasius, and W. J. Roberts (1979). Evolution of Martian polar landscapes: Interplay of long-term variations in perennial ice cover and dust storm intensity.J. Geophys. Res. 84, 2975 2994.

De Villiers, P. R., And J. N. J. Visser (1977). The glacial beds of the Griqualand West Supergroup as revealed by four deep boreholes between Postmasburg and Sishen. Trans. Geol. Soc. S. Afr. 80, 1-8.

Denton, G. H., And T. J. Hughes (1981). The Arctic Ice Sheet: An outrageous hypothesis. In The Last Great Ice Sheets (G. H. Denton and T. J. Hughes, Eds.), pp. 437-467. Wiley, New York.

Denton, G. H., R. L. Armstrong, and M. Stuiver (1971). The late Cenozoic glacial history of Antarctica. In The Late Cenozoic Glacial Ages (K. K. Turekian, Ed.), pp. 267-306. Yale Univ. Press, New Haven.

Destombes, J. (1968). Sur la nature glaciaire des sédiments du groupe du 2 ème Bani, A shgill supérieur de l'Anti-Atlas, Maroc. C.R. hebd. Seances Acad. Sci. Paris Ser. D 267, 684-686.

DEWEY, J. F., AND J. M. BiRD (1970). Mountain belts and the new global tectonics. J. Geophys. Res. 75, 2625-2647.

Deynoux, M., And R. Trompette (1976). Late Precambrian mixtites: Glacial and/or nonglacial? Dealing especially with the mixtites of west Africa. Amer. J. Sci. 276, 1302-1324.

Deynoux, M., and R. Trompette (1981). Late Or- 
dovician tillites of the Taoudeni Basin, west Africa. In Earth's Pre-Pleistocene Glacial Record (M. J. Hambrey and W. B. Harland, Eds.), pp. 89-96. Cambridge Univ. Press, London/New York.

Deynoux, M., O. Dia, J. Sougy, and R. Trompette (1972). La glaciation "Fini-Ordovicienne" en Afrique de l'ouest. Soc. Geol. Mineral. Bretagne Bull. C. IV, 9-16.

Donnel. y, T. H. (1981). Discussion: Sedimentology, stable-isotope geochemistry and palaeoenvironment of dolostones capping late Precambrian glacial sequences in Australia. J. Geol. Soc. Aust. 28, 99101.

Dorman, F. H. (1968). Some Australian oxygen isotope temperatures and a theory for a 30-million-year world-temperature cycle. J. Geol. 76, 297-313.

DotT, R. H., JR. (1961). Squantum "tillite," Massachusetts-Evidence of glaciation or subaqueous mass movements? Geol. Soc. Amer. Bull. 72, 1289 1306.

Drewry, G. E., A. T. S. RAMSAY, AND A. G. SMith (1974). Climatically controlled sediments, the geomagnetic field, and trade wind belts in Phanerozoic time. J. Geol. 82, 531-553.

Dzurisin, D., AND K. R. Blasius (1975). Topography of the polar layered deposits of Mars. J. Geophys. Res. 80, 3286-3306.

EdWARDS, M. B. (1978). Glacial environments. In Sedimentary Environments and Facies (H. G. Reading, Ed.), pp. 416-438. Elsevier, New York/Amsterdam.

Fischer, A. G. (1980). Gilbert-Bedding rhythms and geochronology. Geol. Soc. Amer. Spec. Pap. 183, 93-104.

Fischer, A. G. (1982a). Long-term climatic oscillations recorded in stratigraphy. In Report on Pre-Pleistocene Climates. Nat. Acad. Sci., in press.

Fischer, A. G. (1982b). The 21,000 year shale-limestone rhythm. $J$. Geol. Soc. London 139, in press.

Fischer, A. G., AND M. A. Arthur (1977). Secular variations in the pelagic realm. In Deep-Water Carbonate Environments (H. E. Cook and P. Enos, Eds.), pp. 19-50. Soc. Econ. Paleont. Mineral. Spec. Publ. 25.

FLINT, R. F. (1971). Glacial and Quaternary Geology. Wiley, New York.

Flint, R. F. (1975). Features other than diamicts as evidence of ancient glaciations. In Ice Ages: Ancient and Modern (A. E. Wright and F. Moseley, Eds.), pp. 121-136. Seel House Press, Liverpool.

Flint, R. F., J. E. SANders, ANd J, Rodgers (1960a). Symmictite: A name for nonsorted terrigenous sedimentary rocks that contain a wide range of particle sizes. Geol. Soc. Amer. Bull. 71, 507-510.

Flint, R. F., J. E. Sanders, and J. Rodgers (1960b). Diamictite: A substitute term for symmictite. Geol. Soc. Amer. Bull. 71, 1809-1810.
Frakes, L. A. (1979). Climates Throughout Geologic Time. Elsevier, New York/Amsterdam.

Fuller, A. O. (1958). A contribution to the petrology of the Witwatersrand System. Trans. Geol. Soc. S. Afr. 61, 19-50.

Geitzenauer, K. R., S. V. Margolis, and D. S. EDWARDS (1968). Evidence consistent with Eocene glaciation in a South Pacific deep sea sedimentary core. Earth Planet. Sci. Lett. 4, 173-177.

Hambrey, M. J., and W. B. Harland, Eds. (1981). Earth's Pre-Pleistocene Glacial Record. Cambridge Univ. Press, London/New York.

Harland, W. B. (1964a). Evidence of late Precambrian glaciation and its significance. In Problems in Palaeoclimatology (A. E. M. Nairn, Ed.), pp. 119149. Interscience, New York.

Harland, W. B. (1964b). Critical evidence for a great infra-Cambrian glaciation. Geol. Rundsch. 54, 4561.

HARLAND, W. B. (1981a). Chronology of Earth's glacial and tectonic record. J. Geol. Soc. London 138, 197-203

Harland, W. B. (1981b). The late Archaean(?) Witwatersrand conglomerates, South Africa. In Earth's Pre-Pleistocene Glacial Record (M. J. Hambrey and W. B. Harland, Eds.), pp. 185-187. Cambridge Univ. Press, Cambridge/New York.

Harland, W. B., and E. H. Francis, Eds. (1971). The Phanerozoic Time-Scale. A Supplement. Geol. Soc. Lond. Spec. Publ. 5.

Harland, W. B., and K. N. Herod (1975). Glaciations through time. In Ice Ages: Ancient and Modern (A. E. Wright and F. Moseley, Eds.), pp. 189216. Seel House Press, Liverpool.

Harland, W. B., K. N. Herod, and D. H. KRINSLEY (1966). The definition and identification of tills and tillites. Earth-Sci. Rev. 2, 225-256.

Harland, W. B., A. G. Smith, and B. Wilcock, Eds. (1964). The Phanerozoic Time-Scale. Geol. Soc. Lond. Spec. Publ. 1.

Harrison, J. E., and Z. E. Peterman (1980). North American Commission on Stratigraphic Nomenclature Note 52-A preliminary proposal for a chronometric time scale for the Precambrian of the United States and Mexico. Geol. Soc. Amer. Bull. 91, 377380.

HART, M. H. (1978). A history of the Earth's atmosphere. Icarus 33, 23-39.

Hayes, D. E., and L. A. Frakes (1975). General synthesis. In Initial Reports of the Deep Sea Drilling Project 28, pp. 919-942. U.S. Govt. Printing Office. Washington, D.C.

Hays, J. D., J. Imbrie, and N. J. Shackleton (1976). Variations in the Earth's orbit: Pacemaker of the ice ages. Science 194, 1121-1132.

Head, J. W., and S. C. Solomon (1981). Tectonic evolution of the terrestrial planets. Science 213, 6276. 
HofmanN, H. J. (1973). Stromatolites: Characteristics and utility. Earth-Sci. Rev. 9, 339-373.

Howard, A. D. (1978). Origin of the stepped topography of the Martian poles. Icarus 34, 581-599.

HowarD, A. D. (1982). Etched plains and braided ridges of the south polar region of Mars: Features produced by basal melting of ground ice? In Planet. Geol. Princ. Inv. Meeting, NASA TM, in press.

Howard, A. D., J. A. Cutts, and K. R. Blasius (1982). Stratigraphic relationships within Martian polar cap deposits. Icarus 50, 160-215.

IMBRIE, J. (1982). Review of the astronomical theory of the Pleistocene ice ages. Icarus, in press.

IMBRIE, J., AND J. Z. IMBRIE (1980). Modeling the climatic response to orbital variations. Science $\mathbf{2 0 7}$, 943-953.

IRVING, E., AND J. C. MCGlynN (1976). Proterozoic magnetostratigraphy and the tectonic evolution of Laurentia. Philos. Trans. Roy. Soc. London Ser. A 280, 433-468.

Karlstrom, K. E., AND R. S. Houston (1979). Stratigraphy of the Phantom Lake Metamorphic Suite and Deep Lake Group and a review of the Precambrian tectonic history of the Medicine Bow Mountains. Contrib. Geol. Univ. Wyoming 17, 111133.

KELLER, B. M. (1973). Great glaciations in history of the earth. Int. Geol. Rev. 15, 1067-1074.

KERR, R. A. (1980). Changing global sea levels as a geologic index. Science 209, 483-486.

Kieffer, H. H., S. C. Chase, Jr., T. Z. Martin, E. D. Miner, And F. D. PAlluconi (1976). Martian north pole summer temperatures: Dirty water ice. Science 194, 1341-1344.

KNauth, L. P., And S. Epstein (1976). Hydrogen and oxygen isotope ratios in nodular and bedded cherts. Geochim. Cosmochim. Acta 40, 1095-1108.

KNOLL, A. H., N. Blick, and S. M. AWramik (1981). Stratigraphic and ecologic implications of late Precambrian microfossils from Utah. Amer. $J$. Sci. 281, 247-263.

Lazarus, D. B., AND J. D. HaYs (1981). Late Miocene history of the southern ocean. Geol. Soc. Amer. Abstr. Progr. 13, no. 7, 495.

LeggetT, J. K., W. S. Mc Kerrow, L. R. M. Cocks, AND R. B. RICHARDS (1981). Periodicity in the early Palaeozoic marine realm.J. Geol. Soc. London 138, $167-176$.

LoNG, D. G. F. (1974). Glacial and paraglacial genesis of conglomeratic rocks of the Chibougamau Formation (Aphebian), Chibougamau, Quebec. Canad. $J$. Earth Sci. 11, 1236-1252.

MCCreA, W. H. (1975). Ice ages and the galaxy. Nature (London) 255, 607-609.

McElhinny, M. W. (1973). Palaeomagnetism and Plate Tectonics. Cambridge Univ. Press, London/ New York.

McElhinny, M. W., J. W. Giddings, And B. J. J.
Embleton (1974). Palaeomagnetic results and late Precambrian glaciations. Nature (London) 248, 557-561.

McWilliams, M. O., and M. W. McElhinny (1980). Late Precambrian paleomagnetism of Australia: The Adelaide Geosyncline. J. Geol. 88, 1-26.

Margolis, S. V., and J. P. Kennett (1971). Cenozoic paleoglacial history of Antarctica recorded in subantarctic deep-sea cores. Amer. J. Sci. 271, 136.

Masursky, H., J. M. Boyce, A. L. Dial, G. G. Schaber, ANd M. E. Strobell (1977). Classification and time of formation of Martian channels based on Viking data. J. Geophys. Res. 82, 40164038.

Mathur, S. M. (1981). The Middle Precambrian Gangau Tillite, Bijawar Group, Central India. In Earth's Pre-Pleistocene Glacial Record (M. J. Hambrey and W. B. Harland, Eds.), pp. 428-430. Cambridge Univ. Press, London/New York.

Mayewski, P. A., G. H. Denton, and T. J. Hughes (1981). Late Wisconsin ice sheets of North America. In The Last Great Ice Sheets (G. H. Denton and T. J. Hughes, Eds.), pp. 67-178. Wiley, New York.

Mitchell, J. M., JR. (1976). An overview of climatic variability and its causal mechanisms. Quat. Res. 6, 481-493.

Morel, P., And E. Irving (1978). Tentative paleocontinental maps for the Early Phanerozoic and Proterozoic, J. Geol. 86, 535-561.

Morris, W. A. (1977a). Paleomagnetism of the Gowganda and Chibougamau Formations: Evidence for 2,200-m.y -old folding and remagnetization event of the southern province. Geology 5, 137-140.

Morris, W. A. (1977b). Paleolatitude of glaciogenic upper Precambrian Rapitan Group and the use of tillites as chronostratigraphic marker horizons. Geology 5, 85-88.

Murray, B. C., ANd M. C. Malin (1973). Polar wandering on Mars? Science 179, 997-1000.

Mutch, T. A., R. E. Arvidson, J. W. Head III, K. L. Jones, And R. S. SAunders (1976). The Geology of Mars. Princeton Univ. Press, Princeton, N.J.

NeEthling, D. C. (1970). Geology of the Ahlmann Ridge, Western Queen Maud Land. Map sheet 7 , plate VII, folio 12, Antarctic map folio series, Amer. Geogr. Soc.

NewkIRK, G., JR. (1980). Solar variability on time scales of $10^{5}$ years to $10^{9.6}$ years. In Proc. Conf. Ancient Sun (R. O. Pepin, J. A. Eddy, and R. B. Merrill, Eds.), pp. 293-320.

Nummedal, D. (1978). The role of liquification in channel development on Mars. Rep. Planet. Geol. Prog., NASA TM 79729, 257-259.

Nunes, P. D., AND G. R. Tilton (1971). Uraniumlead ages of minerals from the Stillwater Igneous Complex and associated rocks, Montana. Geol. Soc. Amer. Bull. 82, 2231-2250. 
OJAKANGas, R. W., AND C. L. MAtSCh (1980). Upper Precambrian (Eocambrian) Mineral Fork Tillite of Utah: A continental glacial and glaciomarine sequence. Geol. Soc. Amer. Bull. 91, 495-501.

OWen, T., R. D. Cess, and V. Ramanathan (1979). Infrared $\mathrm{CO}_{2}$ greenhouse to compensate for reduced solar luminosity on early Earth. Nature (London) 277, 640-642.

PAGE, N. J. (1977). Stillwater Complex, Montana: Rock succession, metamorphism and structure of the complex and adjacent rocks. U.S. Geol. Surv. Prof. Pap. 999.

Page, N. J., AND R. A. Koski (1973). A Precambrian diamictite below the base of the Stillwater Complex, southwestern Montana. J. Res. U.S. Geol. Surv. 1, 403-414.

Perry, E. C., AND F. C. TAn (1972). Significance of oxygen and carbon isotope variations in Early Precambrian cherts and carbonate rocks of southern Africa. Geol. Soc. Amer. Bull. 83, 647-664.

Pieri, D. (1976). Distribution of small channels on the Martian surface. Icarus 27, 25-50.

Piper, J. D. A. (1973). Latitudinal extent of Late Precambrian glaciations. Nature (London) 244, 342344.

Piper, J. D. A. (1976). Palaeomagnetic evidence for a Proterozoic supercontinent. Philos. Trans, Roy. Soc. London Ser. A 280, 469-490.

Plafker, G., And W. O. Addicott (1976). Glaciomarine deposits of Miocene through Holocene age in the Yakataga Formation along the Gulf of Alaska margin. In Recent and Ancient Sedimentary Environments in Alaska (T. P. Miller, Ed.), pp. 123. Alaska Geol. Soc., Anchorage.

Pollack, J. B. (1979). Climate change on the terrestrial planets. Icarus 37, 479-553.

Ronov, A. B. (1964). Common tendencies in the chemical evolution of the Earth's crust, ocean and atmosphere. Geochemistry 8, 715-743.

Roscoe, S. M. (1973). The Huronian Supergroup, a Paleoaphebian succession showing evidence of atmospheric evolution. In Huronian Stratigraphy and Sedimentation (G. M. Young, Ed.), pp. 31-47. Geol. Assoc. Canada Spec. Paper 12.

Runcorn, S. K. (1964). The connexion between palaeomagnetism and palaeoclimates. In Problems in Palaeoclimatology (A. E. M. Nairn, Ed.), pp. 191 199. Interscience, New York.

Rust, I. C. (1981). Early Paleozoic Pakhuis Tillite, South Africa. In Earth's Pre-Pleistocene Glacial Record (M. J. Hambrey and W. B. Harland, Eds.), pp. 113-117. Cambridge Univ. Press, London New York.

Sagan, C. (1977). Reducing greenhouses and the temperature history of Earth and Mars. Nature (London) 269, 224-226.

Sagan, C., and G. Mullen (1972). Earth and Mars: Evolution of atmospheres and surface temperatures. Science 177, 52-56.
Sagan, C., O. B. Toon, and P. J. Gierasch (1973). Climatic change on Mars. Science 181, 1045-1049.

SAvin, S. M. (1977). The history of the Earth's surface temperature during the past 100 million years. Annu. Rev. Earth Planet. Sci. 5, 319-355.

SChermerhorN, L. J. G. (1974). Late Precambrian mixtites: Glacial and/or nonglacial? Amer. J. Sci. 274, 673-824.

SCHERMERHoRn, L. J. G. (1975). Tectonic framework of Late Precambrian supposed glacials. In Ice Ages: Ancient and Modern (A. E. Wright and F. Moseley, Eds.), pp. 241-274. Seel House Press, Liverpool.

SchmidT, P. W., AND W. A. Morris (1977). An alternative view of the Gondwana Paleozoic apparent polar wander path. Canad. J. Earth Sci. 14, 26742678 .

Schultz, P. H., AND A. B. Lutz-Garihan (1981). Ancient polar locations on Mars: Evidence and implications. In 3rd Mars Internat. Colloqu. Abstrs. Pasadena, California, pp. 229-231.

SchwarzbaCh, M. (1964). Criteria for the recognition of ancient glaciations. In Problems in Palaeoclimatology (A. E. M. Nairn, Ed.), pp. 81-85. Interscience, New York.

Scotese, C. R., R. K. BAmbach, C. Barton, R. VAN Der Voo, AND A. M. Ziegler (1979). Paleozoic base maps. J. Geol. 87, 217-277.

ShaRP, R. P., AND M. C. MaLin (1975). Channels on Mars. Geol. Soc. Amer. Bull. 86, 593-609.

Spencer, A. M. (1971). Late Pre-Cambrian glaciation in Scotland. Geol. Soc. London. Mem. 6.

SquYres, S. W. (1979). The evolution of dust deposits in the Martian north polar region. Icarus 40, 244261.

Steiner, J. (1967). The sequence of geological events and the dynamics of the Milky Way Galaxy. J. Geol. Soc. Aust. 14, 99-132.

Steiner, J., and E. Grillmair (1973). Possible galactic causes of periodic and episodic glaciations. Geol. Soc. Amer. Bull. 84, 1003-1018.

Symons, D. T. A. (1975). Huronion glaciation and polar wander from the Gowganda Formation, Ontario. Geology 3, 303-306.

TAlbot, R. J., JR., D. M. Butler, AND M. J. NewMAN (1976). Climatic effects during passage of the solar system through interstellar clouds. Nature (London) 262, 561-563.

TARLING, D. H. (1974). A palaeomagnetic study of Eocambrian tillites in Scotland. J. Geol. Soc. London 130, 163-177.

Toon, O. B.. J. B. Pollack, W. Ward, J. A. Burns, AND K. BILSKI (1982). The astronomical theory of climatic change on Mars. Icarus, in press.

Trendall, A. F. (1976). Striated and faceted boulders from the Turee Creek Formation-Evidence for a possible Huronian glaciation on the Australian continent. Geol. Surv. West. Aust. Annu. Rep., 88-92.

Tucker, M. E., AND P. C. ReId (1973). The sedimentology and context of Late Ordovician glacial ma- 
rine sediments from Sierra Leone, West Africa. $\mathrm{Pa}$ laeogeogr. Palaeoclimatol. Palaeoecol. 13, 289307.

Umbgrove, J. H. F. (1947). The Pulse of the Earth, 2nd ed. Martinus Nijhoff, The Hague.

VAIL, P. R., AND J. Hardenbol (1979). Sea-level changes during the Tertiary. Oceanus 22, 71-79.

VAIL, P. R., R. M. Mitchum, JR., and S. Thompson III (1977a). Seismic stratigraphy and global changes of sea level, part 3: Relative changes of sea level from coastal onlap. In Seismic Stratigraphy-Applications to Hydrocarbon Exploration (C. E. Payton, Ed.), pp. 63-81. Am. Assoc. Petrol Geol. Mem. 26.

VAll, P. R., R. M. Mitchum, JR., AND S. Thompson III (1977b). Seismic stratigraphy and global changes of sea level, part 4: Global cycles of relative changes of sea level. In Seismic Stratigraphy-Applications to Hydrocarbon Exploration (C. E. Payton, Ed.), pp. 83-97. Am. Assoc. Petrol. Geol. Mem. 26.

VAN Eysinga, F. W. B., Compiler. (1975). Geological Time Table. Elsevier, Amsterdam/New York.

Van NJekirk, C. B., AND A. J. Burger (1978). A new age for the Ventersdorp acidic lavas. Trans. Geol. Soc. S. Afr. 81, 155-163.

VISSER, J. N. J. (1971). The deposition of the Griquatown Glacial Member in the Transvaal Supergroup. Trans. Geol. Soc. S. Afr. 74, 187-199.

VISSER, J. N. J. (1981). The Mid-Precambrian tillite in the Griqualand West and Transvaal Basins, South Africa. In Earth's Pre-Pleistocene Glacial Record (M. J. Hambrey and W. B. Harland, Eds.), pp. 180184. Cambridge Univ. Press, London/New York.

WALKER, J . C. G. (1976). Implications for atmospheric evolution of the inhomogeneous accretion model of the origin of the Earth. In The Early History of Earth (B. F. Windley, Ed.), pp. 537-546. Wiley, New York.

WALKer, J. C. G. (1977). Evolution of the Atmosphere. Macmillan Co., New York.

Walter, M. R., Ed. (1976). Stromatolites. Dev. Sedimentol. 20.

WARD, W. R. (1974). Climatic variations on Mars. 1. Astronomical theory of insolation.J. Geophys. Res. 79, 3375-3386.

WARD, W. R. (1979). Present obliquity oscillations of
Mars: Fourth-order accuracy in orbital $e$ and $I . J$. Geophys. Res. 84, 237-241.

WARD, W. R. (1982). Comments on the long-term stability of the Earth's obliquity. Icarus 50, 444-448.

Ward, W. R., J. A. Burns, AND O. B. Toon (1979). Past obliquity oscillations of Mars: The role of the Tharsis Uplift. J. Geophys. Res. 84, 243-259.

Warren, G. (1962). Mawson Tillite. New Zealand Geol. Surv. Bull. 71, 117-122.

Wiebols, J. H. (1955). A suggested glacial origin for the Witwatersrand conglomerates. Trans. Geol. Soc. S. Afr. 58, 367-387.

Williams, G. E. (1972). Geological evidence relating to the origin and secular rotation of the solar system. Mod. Geol. 3, 165-181.

Williams, G. E. (1973). Geotectonic cycles, lunar evolution, and the dynamics of the Earth-Moon system. Mod. Geol. 4, 159-183.

Williams, G. E. (1975a). Late Precambrian glacial climate and the Earth's obliquity. Geol. Mag. 112, 441-465.

Williams, G. E. (1975b). Possible relation between periodic glaciation and the flexure of the galaxy. Earth Planet. Sci. Lett. 26, 361-369.

Williams, G. E. (1979). Sedimentology, stable-isotope geochemistry and palaeoenvironment of dolostones capping late Precambrian glacial sequences in Australia. J. Geol. Soc. Aust. 26, 377-386.

Williams, G. E. (1981). Reply: Sedimentology, stable-isotope geochemistry and palaeoenvironment of dolostones capping late Precambrian glacial sequences in Australia. J. Geol. Soc. Aust. 28, 102105.

Williams, G. E., AND P. M. Austin (1973). Global tectonics and the earth's rotation. Mod. Geol. 4, 185-199.

Windley, B. F. (1977). The Evolving Continents. Wiley, New York.

YounG, G. M. (1970). An extensive early Proterozoic glaciation in North America? Palaeogeogr. Palaeoclimatol. Palaeoecol. 7, 85-101.

YounG, G. M. (1973). Tillites and aluminous quartzites as possible time markers for middle Precambrian (Aphebian) rocks of North America. In Huronian Stratigraphy and Sedimentation (G. M. Young, Ed.), pp. 97-127. Geol. Assoc. Canad. Spec. Paper 12. 